\title{
Towards a Thermal Optimization of a Methane/Steam Reforming Reactor
}

\author{
M. Mozdzierz ${ }^{1,2}$ • G. Brus $^{1}$ • A. Sciazko ${ }^{1,2}$. \\ Y. Komatsu ${ }^{2}$-S. Kimijima ${ }^{2}$ - J. S. Szmyd ${ }^{1}$
}

Received: 21 November 2014 / Accepted: 10 December 2015 / Published online: 8 January 2016

(C) The Author(s) 2016. This article is published with open access at Springerlink.com

\begin{abstract}
Plug-flow reactors are very common in methane/steam reforming applications. Their operation presents many challenges, such as a strong dependence on temperature and inlet composition distribution. The strong endothermic steam reforming reaction might result in a temperature drop at the inlet of the reactor. The strong non-uniform temperature distribution due to an endothermic chemical reaction can have tremendous consequences on the operation of the reactor, such as catalyst degradation, undesired side reactions and thermal stresses. One of the possibilities to avoid such unfavorable conditions and control thermal circumstances inside the reforming reactor is to use it as a fuel processor in the solid oxide fuel cell (SOFC) system. The heat generated by exothermic electrochemical SOFC reactions can support the endothermic reforming reaction. Furthermore, the thermal effects of electrochemical reactions help to shape the uniform temperature distribution. To examine thermal management issues, a detailed modeling and corresponding numerical analyses of the phenomena occurring inside the internal reforming system is required. This paper presents experimental and numerical studies on the methane/steam reforming process inside a plug-flow reactor. Measurements including different thermal boundary conditions, the fuel flow rate and the steam-to-methane ratios were performed. The reforming rate equation derived from experimental data was used in the numerical model to predict gas composition and temperature distribution along the steam reforming reactor. Finally, an attempt was made to control the temperature distribution by adopting locally controlled heating zones and non-uniform catalyst density distributions.
\end{abstract}

Keywords Methane/steam reforming · Process control · Plug-flow reactors ·

Solid oxide fuel cells

M. Mozdzierz

marcinm@agh.edu.pl

1 AGH University of Science and Technology, 30-059 Krakow, Poland

2 Shibaura Institute of Technology, 337-8570 Saitama, Japan 


\section{Introduction}

Connecting both high efficiency and fuel flexibility, solid oxide fuel cells (SOFCs) have the potential to become one of the most important energy conversion devices. A solid oxide fuel cell consists of two porous ceramic electrodes (a cathode and an anode) separated by a solid ceramic electrolyte. A typical SOFC uses solid oxides such as yttria-stabilized zirconia (YSZ) for the electrolyte [1]. The operation temperature level of an SOFC is $950[\mathrm{~K}]-1350$ $[\mathrm{K}]$ and it can operate at both atmospheric or elevated pressures [2]. High temperature and non-stoichiometry in the YSZ crystal network allows for the oxygen ions to be transported to the anode side. This is very important because it allows the SOFC to oxidize as a fuel not only hydrogen but also carbon monoxide. The mixture of carbon monoxide and hydrogen can be produced from a wide range of hydrocarbon-based fuels via steam reforming [3-6]. Using hydrocarbons as a fuel has a number of advantages; existing infrastructure can be used to distribute and provide fuels such as city gas to the SOFC systems. Additionally, fuel can be obtained from natural resources and enables us to bypass the hydrogen source problem. For hydrocarbon-based fueled SOFCs, three types of fuel conversion can be considered in the reforming reactions: an external reforming system, an indirect internal reforming system and a direct internal reforming system. High-temperature SOFC eliminates the necessity for an expensive external reforming system. The possibility of using internal reforming is one of the beneficial characteristics of high temperature fuel cells, SOFCs. Strong endothermic fuel reforming reactions can be thermally supported by the transfer, in the form of primarily radiation and convection, of heat by the exothermic electrochemical processes of an SOFC as well as by the passage of electric current. However, for a high-temperature operation, thermal management of the SOFC system becomes an important issue. To carry out properly thermal management, detailed modeling and the numerical analyses of the phenomena occurring inside the SOFC system is required.

Brus and Szmyd studied a temperature distribution in an indirect internal reforming system depending on its location in the system and the distance between the stack and the reactor $[7,8]$. The analyzed reformer had the shape of a rectangular channel and was located above the cell stack in the SOFC system. Their results indicate that the position of the reformer in the module chamber and the emissivity of the surfaces of the reformer, cell and other elements in the SOFC module all play a key role for temperature distribution inside the internal methane/steam reforming reactor $[7,8]$. They determined that by changing the location of the reformer or by modifying the surface property of the reactor, the thermal boundary condition can be changed significantly. Furthermore, the thermo-fluid model of heat and mass transfer inside the indirect internal methane/steam reformer was proposed to conduct parametric studies where the effect of the thermal boundary condition as well as the inlet condition on temperature distribution were investigated $[9,10]$. However, only a uniform thermal boundary condition at the reformer walls and uniform catalyst distribution were investigated $[9,10]$. The model of a parallel-plate reformer was studied by Settar et al. [11]. They showed that proper distribution of a catalyst can improve the efficiency of a methane/steam reformer, but only thin catalyst layers coated to the reformer wall were considered. Additionally, some systems use an internal indirect reformer that has the form of a pipe as can be found in references $[12,13]$. The temperature and species distribution might be significantly different in those systems, therefore additional analyses are required.

Within this work, the authors present an attempt to minimize the temperature gradient along the plug-flow methane/steam reforming reactor by adopting a locally changed thermal 
boundary condition and non-uniform catalyst density distribution. To realize this aim, reaction kinetics have been derived. The empirical rate was employed in the proposed numerical model. The rate and the model were verified by comparing the results of a computation with experimentally obtained data. Finally, a numerical analysis was used to perform parametric studies of temperature and species distributions inside the methane/steam reformer.

\section{Mathematical Model}

The geometry of the assumed cylindrical system together with boundary conditions are presented in Fig. 1. Axisymmetry is assumed, thus the symmetry boundary conditions were imposed at the symmetry axis. The model is steady. Methane $\left(\mathrm{CH}_{4}\right)$ was assumed as the fuel to the system and supplied together with the corresponding amount of steam $\left(\mathrm{H}_{2} \mathrm{O}\right)$ that fulfills the set steam-to-carbon $(S C)$ ratio. The reformer is filled with porous catalyst material, mixture of nickel and yttria-stabilized zirconia (Ni/YSZ). The gaseous fluids are assumed to be Newtonian and the flow of fuel inside the fuel reformer is assumed to be laminar [14], steady and occurring in one direction. The temperature of the in-flow fuel is taken to be instantly approaching the temperature of the reformer.

\subsection{Heat transfer model inside the reformer}

The microstructure of porous media is not being considered directly in the present model, therefore, for the porous area, the governing equations derived by the volume-averaging method are applied [15]. In the adopted method physical values are locally averaged for a representative elementary volume $[16,17]$. The heat transfer process inside the reformer

(b)

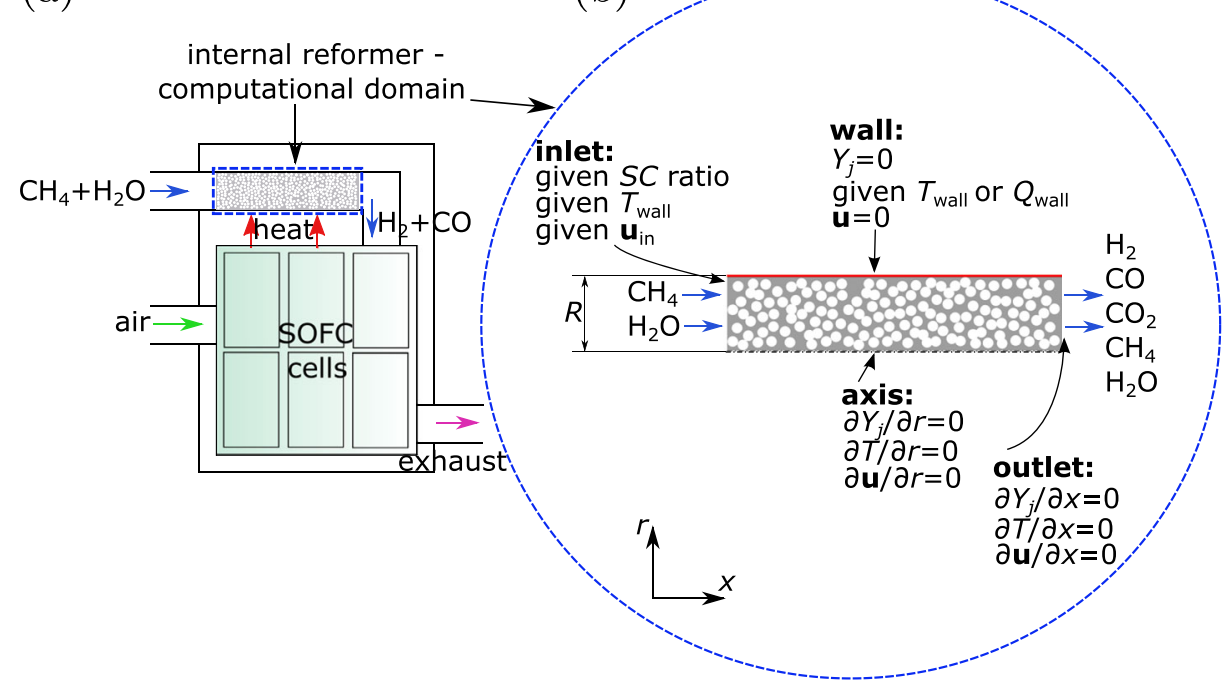

Fig. 1 a Configuration of the system; b Computational domain 
porous media is described by continuity, momentum, energy and mass transfer equations. Consequently, the following transport equations of the volume-averaged physical values for laminar flows apply:

$$
\begin{gathered}
\frac{\partial\left(\rho_{0} U_{x}\right)}{\partial x}+\frac{1}{r} \frac{\partial\left(r \rho_{0} U_{r}\right)}{\partial r}=0 \\
\frac{\rho_{0}}{\epsilon_{0}^{2}}\left(U_{x} \frac{\partial U_{x}}{\partial x}+U_{r} \frac{\partial U_{x}}{\partial r}\right)=-\frac{\partial P}{\partial x}+\frac{\mu}{\epsilon_{0}}\left[\frac{\partial^{2} U_{x}}{\partial x^{2}}+\frac{1}{r} \frac{\partial}{\partial r}\left(r \frac{\partial U_{x}}{\partial r}\right)\right] \\
-\frac{\mu}{K_{\mathrm{p}}} U_{x}-\frac{\rho_{0} f}{\sqrt{K_{\mathrm{p}}}} U_{x} \sqrt{U_{x}^{2}+U_{r}^{2}} \\
\frac{\rho_{0}}{\epsilon_{0}^{2}}\left(U_{x} \frac{\partial U_{r}}{\partial x}+U_{r} \frac{\partial U_{r}}{\partial r}\right)=-\frac{\partial P}{\partial r}+\frac{\mu}{\epsilon_{0}}\left[\frac{\partial^{2} U_{r}}{\partial x^{2}}+\frac{1}{r} \frac{\partial}{\partial r}\left(r \frac{\partial U_{r}}{\partial r}\right)-\frac{U_{r}}{r^{2}}\right] \\
\rho_{0} C_{\mathrm{p}}\left(U_{x} \frac{\partial T}{\partial x}+U_{r} \frac{\partial T}{\partial r}\right)=\frac{\partial}{\partial x}\left(\lambda_{\mathrm{eff}} \frac{\partial T}{\partial x}\right)+\frac{1}{r} \frac{\partial}{\partial r}\left(r \lambda_{\mathrm{eff}} \frac{\partial T}{\partial r}\right)+U_{r}^{2} \\
\rho_{0}\left(U_{x} \frac{\partial Y_{j}}{\partial x}+U_{r} \frac{\partial Y_{j}}{\partial r}\right)=\frac{\partial}{\partial x}\left(\rho_{0} D_{j, \text { eff }} \frac{\partial Y_{j}}{\partial x}\right)+\frac{1}{r} \frac{\partial}{\partial r}\left(r \rho_{0} D_{j, \text { eff }} \frac{\partial Y_{j}}{\partial r}\right)+S_{j}
\end{gathered}
$$

The physical values in the above equations represent the local phase average of the gas control volume. The porosity of the porous medium was chosen as $\epsilon_{0}=0.7$ [-] and the permeability was $K_{\mathrm{p}}=1.0 \times 10^{-7}\left[\mathrm{~m}^{2}\right]$. The inertia coefficient $f$ depends on the Reynolds number, permeability and the microstructure of the porous medium [17]. Because the pore diameter-based Reynolds number [18] in the current study varies from 0.01 [-] to 0.5 [-], the inertia coefficient was chosen as $f=0.088$ [-], according to [19]. The value of the Reynolds number can also confirm the laminar flow assumption [14]. The effective thermal conductivity $\lambda_{\text {eff }}$ was calculated using Eq. 6 and the solid phase thermal conductivity was $\lambda_{\mathrm{s}}=$ $20.0\left[\mathrm{~W} \mathrm{~m}^{-1} \mathrm{~K}^{-1}\right][19,20]$. The thermophysical properties of the gas mixture (i.e. mixture density, mixture viscosity, mixture thermal conductivity and effective mass diffusivity) were calculated with mixing laws [21].

$$
\lambda_{\text {eff }}=\epsilon_{0} \lambda_{\mathrm{f}}+\left(1-\epsilon_{0}\right) \lambda_{\mathrm{s}}
$$

\subsection{Mathematical model of a reforming process}

The methane/steam reforming process is widely known as a conventional process for producing hydrogen [5]. In the reforming process of methane with steam, the dominant reactions are the following two [22]:

methane/steam reforming reaction:

$$
\mathrm{CH}_{4}+\mathrm{H}_{2} \mathrm{O} \rightarrow 3 \mathrm{H}_{2}+\mathrm{CO}
$$

water-gas-shift reaction:

$$
\mathrm{CO}+\mathrm{H}_{2} \mathrm{O} \rightleftharpoons \mathrm{H}_{2}+\mathrm{CO}_{2}
$$


The methane/steam reforming reaction, described by Eq. 7, is slow, therefore a rate equation is needed. The water-gas-shift reaction described by Eq. 8 is fast and can be assumed to be in equilibrium at the reforming temperature $[5,22,23]$.

The rate of the methane/steam reforming reaction (7) is based on experimental data and can be locally calculated as follows:

$$
R_{\mathrm{st}}=\dot{w}_{\mathrm{cat}} A_{\mathrm{st}} \exp \left(-\frac{E_{\mathrm{a}}}{\bar{R} T}\right) p_{\mathrm{CH}_{4}}^{a} p_{\mathrm{H}_{2} \mathrm{O}}^{b}
$$

The water-gas-shift reaction, given by Eq. 8, reaches equilibrium rapidly, therefore $\mathrm{CO}_{2}$, $\mathrm{H}_{2}$, $\mathrm{CO}$ and $\mathrm{H}_{2} \mathrm{O}$ have to satisfy the equilibrium equation:

$$
K_{\mathrm{sh}}=\frac{k_{\mathrm{sh}}^{+}}{k_{\mathrm{sh}}^{-}}=\frac{p_{\mathrm{CO}_{2}} p_{\mathrm{H}_{2}}}{p_{\mathrm{CO} p_{\mathrm{H}_{2} \mathrm{O}}}}=\exp \left(-\frac{\Delta G_{\mathrm{sh}}^{0}}{\bar{R} T}\right)
$$

Introducing to Eq. 10 partial pressures of species derived from stoichiometry of reactions (7) and (8) and transforming Eq. 10, the expression for carbon oxide conversion rate can be formulated:

$$
y c r=\frac{K_{\mathrm{sh}} S C+3 x c r-\sqrt{\left(K_{\mathrm{sh}} S C+3 x c r\right)^{2}-4 K_{\mathrm{sh}} x c r\left(K_{\mathrm{sh}}-1\right)(S C-x c r)}}{2\left(K_{\mathrm{sh}}-1\right)}
$$

The conversion rate of methane is related to the rate of methane/steam reforming reaction and the molar flow rate of the methane at the reactor inlet:

$$
x c r=1-\frac{n_{\mathrm{CH}_{4}}^{\text {inlet }}-R_{\mathrm{st}} V}{n_{\mathrm{CH}_{4}}^{\text {inlet }}}
$$

The rate of water-gas shift reaction is also related to the methane molar flow rate at the inlet through reactions' stoichiometry:

$$
R_{\mathrm{sh}}=\frac{n_{\mathrm{CO}_{2}}^{\text {outlet }}}{V}=\frac{n_{\mathrm{CH}_{4}}^{\text {inlet }} \cdot x c r}{V} y c r
$$

After the introduction of Eq. 12 to Eq. 13, the final relation for the local rate of water-gas shift reaction can be obtained:

$$
R_{\mathrm{sh}}=R_{\mathrm{st}} y c r
$$

The mass production or consumption rate of each chemical species by the methane/steam reforming reaction (Eq. 7) and water-gas-shift reaction (8) is shown in Table 1. The value of the mole production or consumption rate for each chemical species is introduced into the species' mass transfer equation (Eq. 5) as a part of its source term.

The thermodynamic heat generation rates by the methane/steam reforming reaction and water-gas-shift reaction (7) and (8) are calculated based on the reaction rates, as follows:

$$
\begin{gathered}
Q_{\mathrm{st}}=-\Delta H_{\mathrm{st}} R_{\mathrm{st}} \\
Q_{\mathrm{sh}}=-\Delta H_{\mathrm{sh}} R_{\mathrm{sh}}
\end{gathered}
$$


Table 1 Mass sources/sinks

\begin{tabular}{llll}
\hline species & $\begin{array}{l}\text { rate of production/ } \\
\text { consumption in methane } \\
\text { /steam reforming reaction }\end{array}$ & $\begin{array}{l}\text { rate of production/ } \\
\text { consumption in water-gas } \\
\text {-shift reaction }\end{array}$ & total mass source/sink \\
\hline $\mathrm{H}_{2}$ & $3 R_{\mathrm{st}} M_{\mathrm{H}_{2}}$ & $R_{\mathrm{sh}} M_{\mathrm{H}_{2}}$ & \\
$\mathrm{CO}$ & $R_{\mathrm{st}} M_{\mathrm{CO}}$ & $-R_{\mathrm{sh}} M_{\mathrm{CO}}$ & $3 R_{\mathrm{st}} M_{\mathrm{H}_{2}}+R_{\mathrm{sh}} M_{\mathrm{H}_{2}}$ \\
$\mathrm{CO}_{2}$ & 0 & $R_{\mathrm{sh}} M_{\mathrm{CO}_{2}}$ & $R_{\mathrm{st}} M_{\mathrm{CO}}-R_{\mathrm{sh}} M_{\mathrm{CO}}$ \\
$\mathrm{CH}_{4}$ & $-R_{\mathrm{st}} M_{\mathrm{CH}}$ & 0 & $R_{\mathrm{sh}} M_{\mathrm{CO}_{2}}$ \\
$\mathrm{H}_{2} \mathrm{O}$ & $-R_{\mathrm{st}} M_{\mathrm{H}_{2} \mathrm{O}}$ & $-R_{\mathrm{sh}} M_{\mathrm{H}_{2} \mathrm{O}}$ & $-R_{\mathrm{st}} M_{\mathrm{CH}_{4}}$ \\
\hline
\end{tabular}

\subsection{Discretization scheme}

All partial differential equations given in Section 2.1 can be presented in the following universal form:

$$
\Psi_{x} \frac{\partial \phi}{\partial x}+\Psi_{r} \frac{\partial \phi}{\partial r}=\frac{\partial}{\partial x}\left(\Gamma \frac{\partial \phi}{\partial x}\right)+\frac{1}{r} \frac{\partial}{\partial r}\left(r \Gamma \frac{\partial \phi}{\partial r}\right)+\bar{S}
$$

Values of coefficients which appear in Eq. 17 arise from transport equations 2, 3, 4 and 5 and they are presented in Table 2 .

For the considered problem the discretization of governing equations has been done using the Finite Volume Method [24, 25]. The staggered grid system is adopted to solve momentum transport equations: the second grid, designed to store values of velocity in $x$ and $r$ directions, is shifted in position from the grid to store scalar values (pressure, temperature and concentrations) (see Fig. 2). The general transport equation, (17), is integrated through the control volume, painted in grey in Fig. 2, and the discretized equation can be written:

$$
\begin{array}{r}
{\left[\left(\Psi_{x} \phi\right)_{\mathrm{e}}-\left(\Psi_{x} \phi\right)_{\mathrm{w}}\right] r_{\mathrm{m}} \Delta r+\left[\left(r \Psi_{r} \phi\right)_{\mathrm{n}}-\left(r \Psi_{r} \phi\right)_{\mathrm{s}}\right] \Delta x} \\
=\left[\left(\Gamma \frac{\partial \phi}{\partial x}\right)_{\mathrm{e}}-\left(\Gamma \frac{\partial \phi}{\partial x}\right)_{\mathrm{w}}\right] r_{\mathrm{m}} \Delta r+\left[\left(r \Gamma \frac{\partial \phi}{\partial r}\right)_{\mathrm{n}}-\left(r \Gamma \frac{\partial \phi}{\partial r}\right)_{\mathrm{s}}\right] \Delta x \\
+\bar{S} r_{\mathrm{m}} \Delta r \Delta x
\end{array}
$$

Where $r_{\mathrm{m}}$ stands for the arithmetic mean:

\begin{tabular}{|c|c|c|c|c|c|}
\hline Eq. & $\phi$ & $\Psi_{x}$ & $\Psi_{r}$ & $\Gamma$ & $\bar{S}$ \\
\hline 2 & $U_{x}$ & $\frac{\rho_{0}}{\epsilon_{0}^{2}} U_{x}$ & $\frac{\rho_{0}}{\epsilon_{0}^{2}} U_{r}$ & $\frac{\mu}{\epsilon_{0}}$ & $-\frac{\partial P}{\partial x}-\frac{\mu}{K_{\mathrm{p}}} U_{x}-\frac{\rho_{0} f}{\sqrt{K_{\mathrm{p}}}} U_{x} \sqrt{U_{x}^{2}+U_{r}^{2}}$ \\
\hline 3 & $U_{r}$ & $\frac{\rho_{0}}{\epsilon_{0}^{2}} U_{r}$ & $\frac{\rho_{0}}{\epsilon_{0}^{2}} U_{r}$ & $\frac{\mu}{\epsilon_{0}}$ & $-\frac{\partial P}{\partial r}-\frac{\mu}{K_{\mathrm{p}}} U_{r}-\frac{\rho_{0} f}{\sqrt{K_{\mathrm{p}}}} U_{r} \sqrt{U_{x}^{2}+U_{r}^{2}}-\frac{\mu U_{r}}{\epsilon_{0} r^{2}}$ \\
\hline 4 & $T$ & $\rho_{0} C_{\mathrm{p}} U_{x}$ & $\rho_{0} C_{\mathrm{p}} U_{r}$ & $\lambda_{\text {eff }}$ & $Q_{\mathrm{s}}$ \\
\hline 5 & $Y_{j}$ & $\rho_{0} U_{x}$ & $\rho_{0} U_{r}$ & $\rho_{0} D_{j, \mathrm{eff}}$ & $S_{j}$ \\
\hline
\end{tabular}

$$
r_{\mathrm{m}}=\frac{r_{\mathrm{n}}+r_{\mathrm{s}}}{2}
$$

Table 2 Coefficients in Eq. 17 for different governing equations 


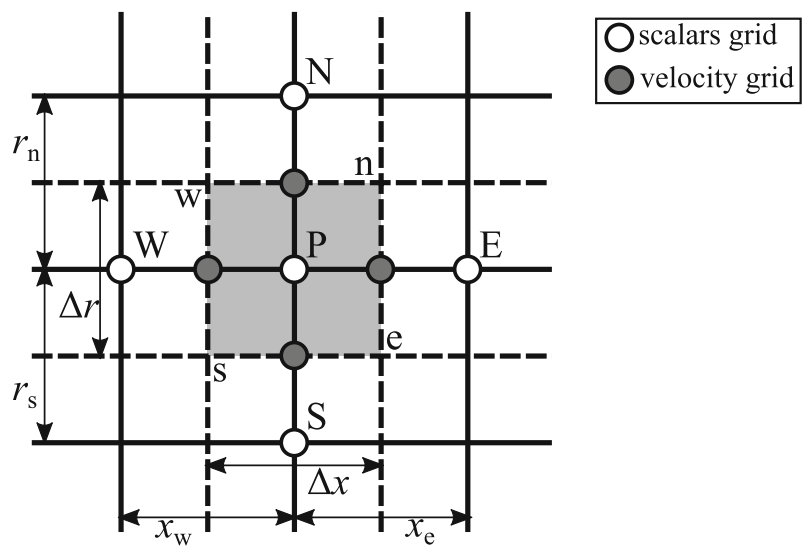

Fig. 2 Grid used to discretize transport equations

After simple mathematical transformations, the general transport equation, (18), can be presented in the following form:

$$
a_{\mathrm{P}} \phi_{\mathrm{P}}=a_{\mathrm{E}} \phi_{\mathrm{E}}+a_{\mathrm{W}} \phi_{\mathrm{W}}+a_{\mathrm{N}} \phi_{\mathrm{N}}+a_{\mathrm{S}} \phi_{\mathrm{S}}+b
$$

Where:

$$
\begin{gathered}
a_{\mathrm{E}}=\frac{\Gamma r_{\mathrm{m}} \Delta r}{x_{\mathrm{e}}} \max \left[0,\left(1-\frac{0.1 x_{\mathrm{e}}\left|\Psi_{x} r_{\mathrm{m}} \Delta r\right|}{\Gamma r_{\mathrm{m}} \Delta r}\right)^{5}\right]+\max \left(0,-\Psi_{x} r_{\mathrm{m}} \Delta r\right) \\
a_{\mathrm{P}}=a_{\mathrm{E}}+a_{\mathrm{W}}+a_{\mathrm{N}}+a_{\mathrm{S}} \\
b=\bar{S} r_{\mathrm{m}} \Delta r \Delta x
\end{gathered}
$$

Coefficients $a_{i}$ that appear in Eq. 20 are the fluxes through the control volume faces and they are determined using the Power Law scheme suggested by Patankar [24]. An example of interface e is presented in Eq. 21, and for other interfaces similar expressions are used. The velocity and pressure fields are solved with the SIMPLE scheme [24], and the inlet pressure equals atmospheric pressure.

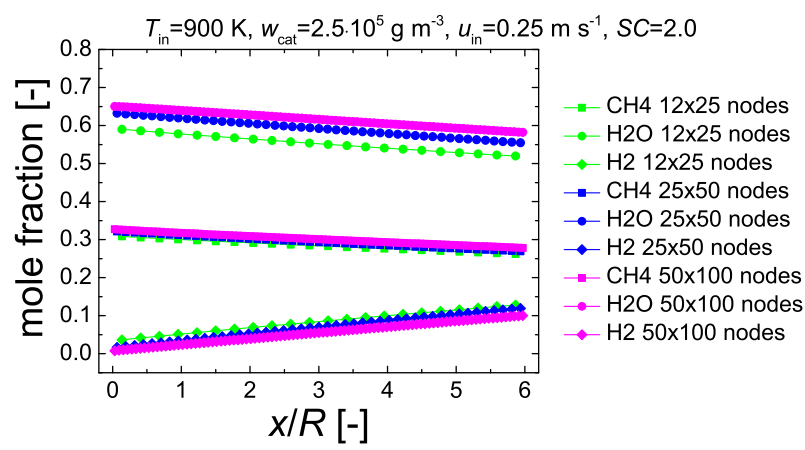

Fig. 3 Average molar fractions of methane, steam and hydrogen along the reformer for three different mesh resolutions 
The source terms are calculated using reaction rates, (9) and (14), and partial pressures of species. Partial pressures can be computed with molar fractions of species, as follows:

$$
p_{j}=P \frac{Y_{j}}{\sum_{j=1}^{n} Y_{j}}
$$

Where pressure $P$ was estimated with the SIMPLE algorithm for every grid point, as mentioned earlier.

Based on the mathematical model and discretization scheme presented above, the in-house methane/steam reforming simulation code in $\mathrm{C}++$ programming language was prepared. The partial differential equations were discretized with the Finite Volume Method The resulting systems of algebraic equations were solved using the Gauss-Seidel method. The equations were solved iteratively while the convergence criteria was achieved. If heat and mass source terms do not change during the iterations, convergence is reached.

The mesh is quadrilateral and structured. The grid resolution was chosen as 50x 25 and the grid independence study showed that a higher resolution did not significantly change the results (see Fig. 3).

\section{Experimental Investigation}

\subsection{Experimental set-up}

A schematic view of the experimental setup is shown in Fig. 4. A stainless steel reformer was located in an electrical furnace, which can be heated up to $800\left[{ }^{\circ} \mathrm{C}\right]$. High purity methane was the fuel used in the experiment. It was supplied to the reformer via a flow controller and evaporator, which was also used as a pre-heater. Water was fed to the system with a pump. The gas composition after the reforming process was analyzed by gas chromatography prior to which the steam had been separated by cooling down the gas mixture to $2\left[{ }^{\circ} \mathrm{C}\right]$. The reforming reaction tube was filled by a nickel supported on the yttria stabilized zirconia. The catalyst material was industrial catalyst provided by AGC Seimi Chemical Co. Ltd. (see Table 3 to check the properties). To control the thermal condition of the experiment, four thermocouples were placed in the experimental set-up as shown in Fig. 4 (marked as $T$ ). To derive correct kinetics data, the reaction has to occur in a whole volume of catalyst. This can be accomplished by keeping the reforming conversion rate low. To achieve a low

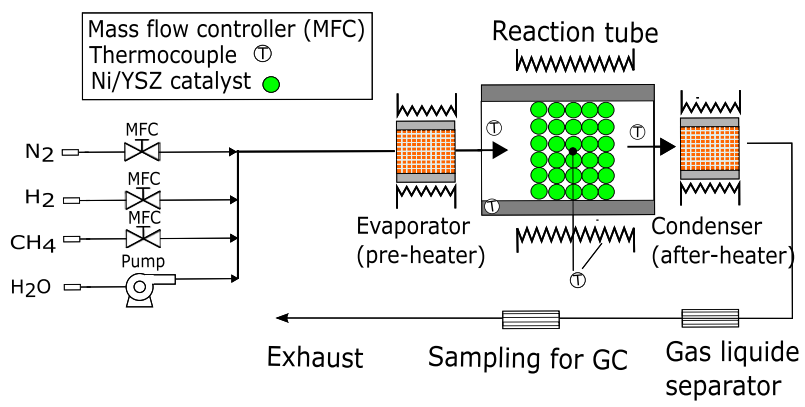

Fig. 4 Schematic view of the experimental setup 
Table 3 Catalyst properties

\begin{tabular}{lllll}
\hline type & nickel contain & particle size & specific surface area & mass of nickel \\
\hline $\mathrm{Ni} / \mathrm{YSZ}$ & $60 \%$ vol. & $0.85 \mu \mathrm{m}$ & $5.2 \mathrm{~m}^{2} \mathrm{~g}^{-1}$ & $1.887 \mathrm{~g}$ \\
\hline
\end{tabular}

level of methane conversion, the fuel was additionally mixed with nitrogen. Nitrogen does not directly influence the methane/steam reforming reaction but the partial pressure of the components changed, which decreases both the reaction rate and methane conversion rate. All measurements presented in this paper have been performed at atmospheric pressure. The geometrical properties of the reactor have been summarized in Table 4.

\subsection{Reaction rate equation}

The mathematical forms of expression describing the kinetics of the methane/steam reforming process can be categorized by three basic concepts [6, 10, 23, 26-29]: i) general Langmuir-Hinshelwood kinetics [5], ii) first order reaction with respect to methane [23, 26] and iii) power-law expressions derived from data fitting [10, 27-29]. In this study, the primarily assumed form of the equation describing the methane/steam reforming kinetic is the power-law expression with respect to the partial pressures of methane and steam. This form of kinetic equation is commonly used in thermo-fluid models of methane/steam reforming reactors $[19,20,30,31]$. Therefore, the rate equation (see Eq. 9) takes the following form:

$$
R_{\mathrm{st}}=\dot{w}_{\mathrm{cat}} A_{\mathrm{st}} \exp \left(-\frac{E_{\mathrm{a}}}{\bar{R} T}\right) p_{\mathrm{CH}_{4}}^{0.89} p_{\mathrm{H}_{2} \mathrm{O}}^{0.05}
$$

Where $A_{\mathrm{st}}=1.354 \times 10^{-3}\left[\mathrm{~mol} \mathrm{~s}^{-1} \mathrm{~g}^{-1} \mathrm{~Pa}^{-(0.94)}\right]$ and $E_{\mathrm{a}}=122500\left[\mathrm{~J} \mathrm{~mol}^{-1}\right]$.

Equation 25 has been determined using the method described in references [27, 32-34]. In this method, the water-gas-shift reaction (8) is assumed to be in equilibrium because of the high temperature inside the reactor. The effects of the supply gas composition are first examined by varying the values of $S C$ (the steam-carbon ratio) and $N C$ (the nitrogencarbon ratio) at a constant temperature to determine the values of the exponential indexes $a$ and $b$ from Eq. 9. Then, experiments are conducted varying the temperature while keeping the supply gas composition unchanged. The reaction constant $k$ is constant for the given temperature, therefore $A$ and $E$ can be determined from the Arrhenius plot. The generalized least squares method, described in references [34,35], was used to correct the experimental data.

\section{Results}

Parametric studies of a methane/steam reformer are usually presented in the form of a temperature and species distribution $[9,10]$. This approach is adopted also in the presented

Table 4 Reactor properties

\begin{tabular}{lllr}
\hline type & catalyst bed thickness & diameter & length \\
\hline stainless steel & $\sim 1 \mathrm{~mm}$ & $25.4 \mathrm{~mm}$ & $450 \mathrm{~mm}$ \\
\hline
\end{tabular}


Fig. 5 Experimental results compared to numerical simulation

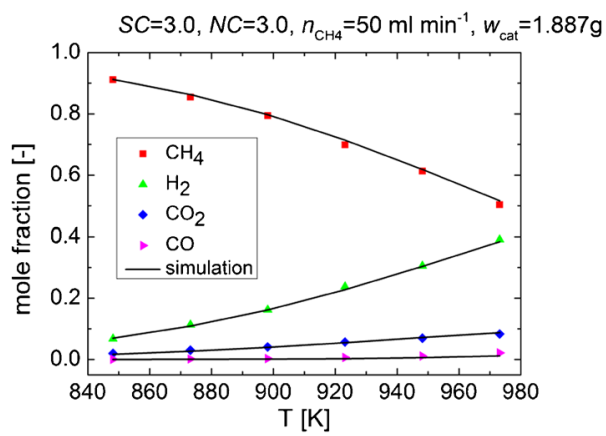

studies. From the perspective of parametric studies the most important parameters are: temperature, inlet flow rate of fuel and catalyst density. The effect of these parameters on temperature and species distribution in the longitudinal direction of a cylindrical plug-flow reformer is studied in this section. Current investigations have rather qualitative than quantitative values therefore the results are presented in dimensionless geometry. Moreover, the comparison between the results of numerical simulation and the results of experimental investigation, presented in Section 3, is presented in order to verify if the numerical model has been build correctly.

\subsection{Verification of the numerical model}

The numerical model presented in Section 2.2 coupled with the rate equation from Section 3.2, enables the prediction of the gas composition at the outlet of the reformer based on the inlet conditions. Examples of numerical results and their comparison with the experimental data are shown in Fig. 5. In this study, the effect of the temperature on the methane/steam reforming reaction was studied by increasing the reaction temperature from $773[\mathrm{~K}]$ to $973[\mathrm{~K}]$. The data shows the outlet dry gas composition to be a function of the reaction temperature. Predictably, the outlet molar fraction of methane decreases

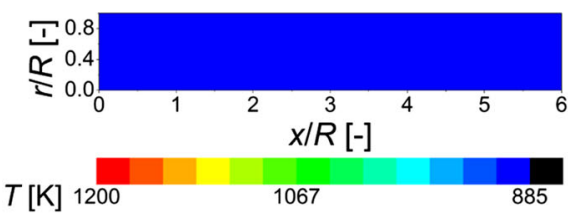

(a) $900 \mathrm{~K}$

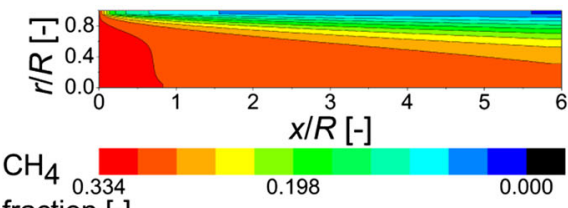

fraction [-]

(c) $900 \mathrm{~K}$

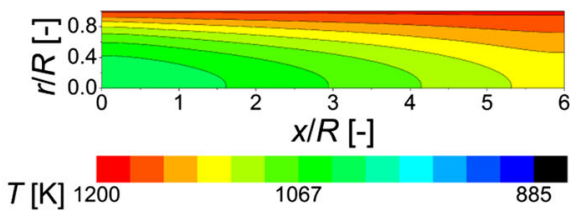

(b) $1200 \mathrm{~K}$

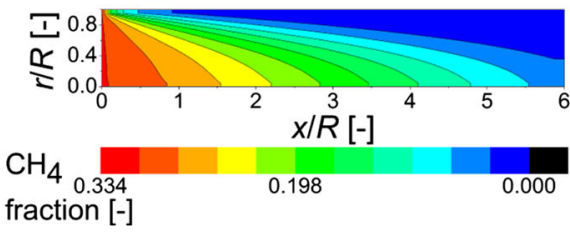

(d) $1200 \mathrm{~K}$

Fig. 6 Distribution of temperature (a-b) and the mole fraction of methane (c-d) for different thermal boundary conditions; $\dot{w}_{\text {cat }}=2.5 \times 10^{5} \mathrm{~g} \mathrm{~m}^{-3}, u_{\text {in }}=0.25 \mathrm{~m} \mathrm{~s}^{-1}, S C=2$. 


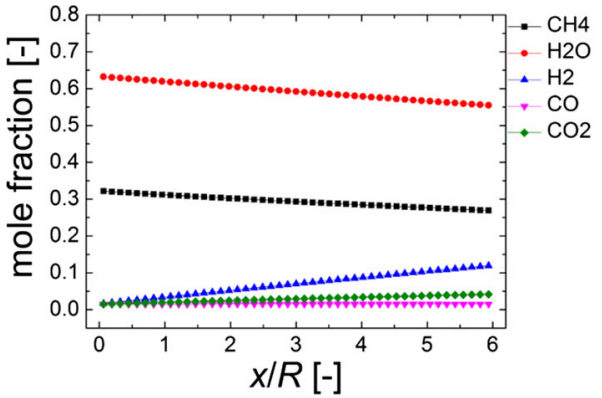

(a) $900 \mathrm{~K}$

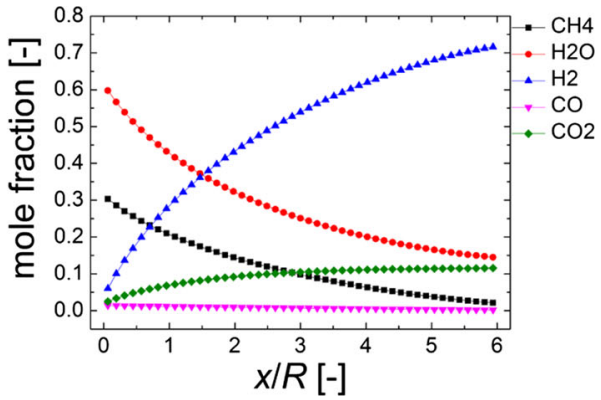

(b) $1200 \mathrm{~K}$

Fig. 7 Average gas composition along the reformer for different thermal boundary conditions; $\dot{w}_{\text {cat }}=2.5 \times$ $10^{5} \mathrm{~g} \mathrm{~m}^{-3}, u_{\text {in }}=0.25 \mathrm{~m} \mathrm{~s}^{-1}, S C=2$.

with increasing reaction temperature and the amount of carbon monoxide increases as the reaction temperature increases. This observation is significant because, in contrast to the low-temperature fuel cell, the carbon monoxide does not poison the high temperature solid oxide fuel cell anode but can be electrochemically converted as a fuel [23].

\subsection{The effects of temperature}

Figures 6 and 7 show the results of numerical computations for the Ni/YSZ catalyst calculated for the different reformer wall temperatures, which varied from 900 [K] to $1200[\mathrm{~K}]$. The volumetric average change of the molar fraction of the gas components in the longitudinal direction of the fuel reformer is illustrated in Fig. 7, which shows that the methane conversion process is strongly affected by the reaction temperature. The mole fraction of hydrogen increase and the mole fractions of methane and steam decrease with the reaction temperature because of the increasing methane conversion rate. Figure 7 shows that carbon

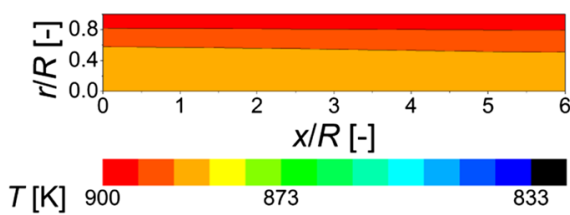

(a) $\dot{w}_{\text {cat }}=2.5 \times 10^{5} \mathrm{~g} \mathrm{~m}^{-3}$

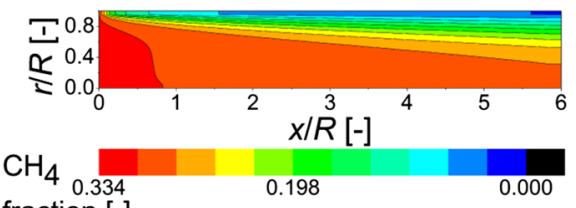
fraction [-]

$$
\text { (c) } \dot{w}_{\text {cat }}=2.5 \times 10^{5} \mathrm{~g} \mathrm{~m}^{-3}
$$

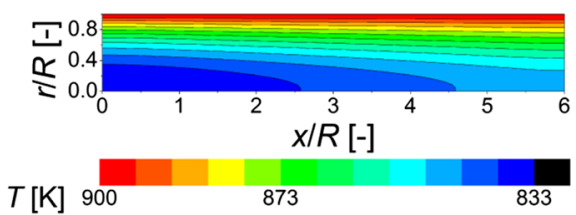

(b) $\dot{w}_{\text {cat }}=2.5 \times 10^{6} \mathrm{~g} \mathrm{~m}^{-3}$

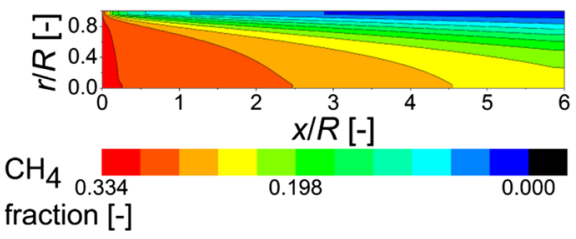

$$
\text { (d) } \dot{w}_{\text {cat }}=2.5 \times 10^{6} \mathrm{~g} \mathrm{~m}^{-3}
$$

Fig. 8 Distribution of temperature (a-b) and the mole fraction of methane (c-d) for different catalyst densities; $T=900 \mathrm{~K}, u_{\text {in }}=0.25 \mathrm{~m} \mathrm{~s}^{-1}, S C=2$. 


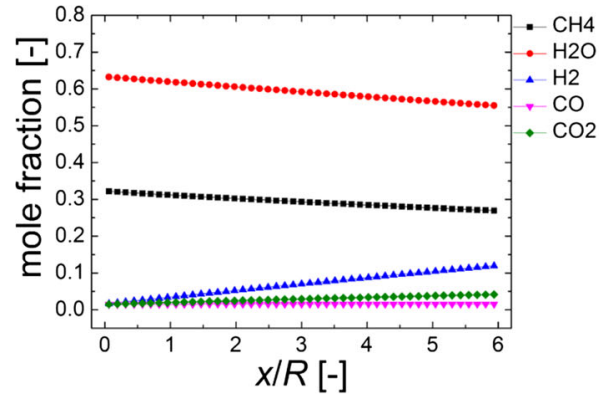

(a) $\dot{w}_{\text {cat }}=2.5 \times 10^{5} \mathrm{~g} \mathrm{~m}^{-3}$

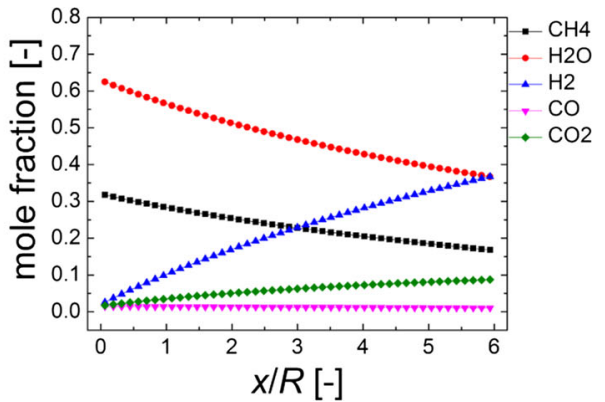

(b) $\dot{w}_{\text {cat }}=2.5 \times 10^{6} \mathrm{~g} \mathrm{~m}^{-3}$

Fig. 9 Average gas composition along the reformer; $T=900 \mathrm{~K}, u_{\text {in }}=0.25 \mathrm{~m} \mathrm{~s}^{-1}, S C=2$.

dioxide increases slightly with the reaction temperature while carbon monoxide remains unchanged and at a low level. The carbon monoxide produced by methane/steam reforming is almost completely consumed in the water-gas-shift reaction. Optimization of the process to achieve full conversion of the carbon monoxide to hydrogen by the water-gas-shift reaction can be accomplished by changing the reaction temperature. This is possible for those reaction temperatures which are favorable for a forward water-gas-shift reaction [36].

\subsection{The effect of catalyst density}

Figures 8 and 9 show the results of numerical computations for different Ni/YSZ catalyst densities. The temperature of the reformer walls equals $T=900[\mathrm{~K}]$, and the inlet fuel velocity $u_{\text {in }}$ equals $0.25\left[\mathrm{~m} \mathrm{~s}^{-1}\right]$. The catalyst weight density was varied from $\dot{w}_{\text {cat }}=2.5 \times$ $10^{5}\left[\mathrm{~g} \mathrm{~m}^{-3}\right]$ to $\dot{w}_{\text {cat }}=2.5 \times 10^{6}\left[\mathrm{~g} \mathrm{~m}^{-3}\right]$. The volumetric average changes in the molar fraction of the gas components in the longitudinal direction of the fuel reformer are illustrated in Fig. 9. Figure 8 presents the temperature distribution and the distribution of methane inside the reformer in the longitudinal direction of the fuel reformer for varied catalyst densities.

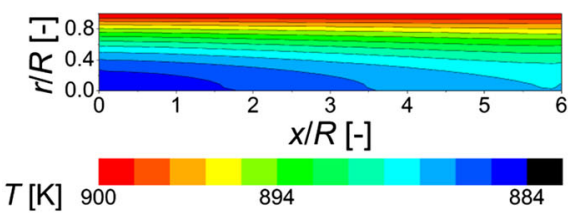

(a) $U_{\text {in }}=0.1 \mathrm{~m} \mathrm{~s}^{-1}$

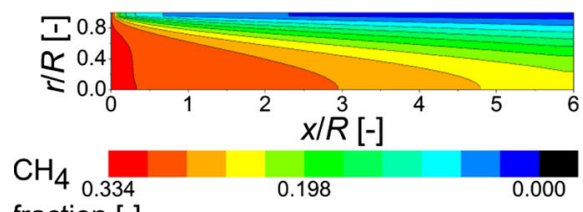

fraction [-]

$$
\text { (c) } U_{\mathrm{in}}=0.1 \mathrm{~m} \mathrm{~s}^{-1}
$$

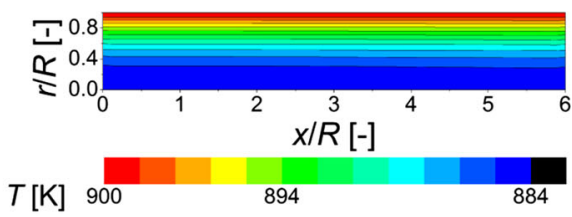

(b) $U_{\text {in }}=1.0 \mathrm{~m} \mathrm{~s}^{-1}$

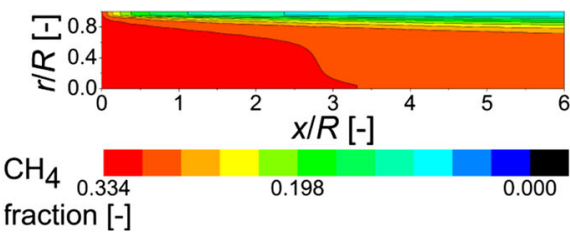

(d) $U_{\text {in }}=1.0 \mathrm{~m} \mathrm{~s}^{-1}$

Fig. 10 Distribution of temperature (a-b) and the mole fraction of methane (c-d) for different inlet velocities of methane; $T=900 \mathrm{~K}, \dot{w}_{\text {cat }}=2.5 \times 10^{5} \mathrm{~g} \mathrm{~m}^{-3}, S C=2$. 


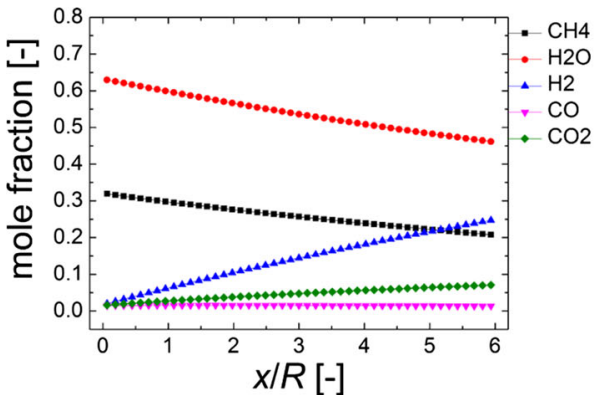

(a) $U_{\text {in }}=0.1 \mathrm{~m} \mathrm{~s}^{-1}$

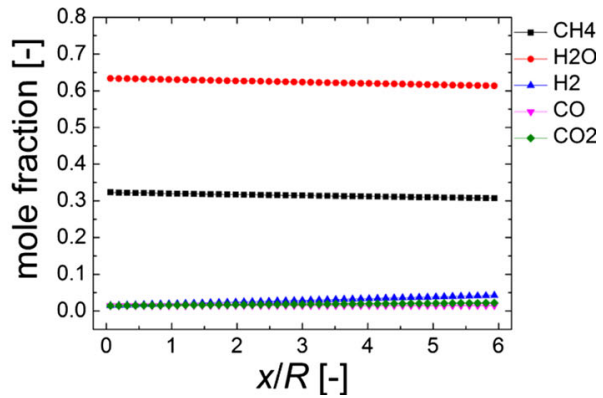

(b) $U_{\text {in }}=1.0 \mathrm{~m} \mathrm{~s}^{-1}$

Fig. 11 Average gas composition along the reformer; $T=900 \mathrm{~K}, \dot{w}_{\text {cat }}=2.5 \times 10^{5} \mathrm{~g} \mathrm{~m}^{-3}, S C=2$.

As is evident in Fig. 8, the methane distribution in the longitudinal direction of the fuel reformer is strongly affected by the catalyst density adapted in the numerical tests. When the catalyst weight density is not sufficient, the methane might leave the reformer unreacted. However, if the catalyst density is too high, a huge temperature gradient may appear as a result of a strong endothermic methane/steam reforming reaction at the reformer inlet as presented in Fig. 8b.

\subsection{The effect of fuel inlet velocity}

Another important parameter for optimization of the fuel reforming process for the SOFC application is the fuel inlet velocity. Examples of numerical results for different inlet velocities are presented in Figs. 10 and 11. The temperature of the reformer walls equals $T=900$ $[\mathrm{K}]$, the steam-to-methane ratio is $S C=2.0$. The catalyst weight density was assumed to be

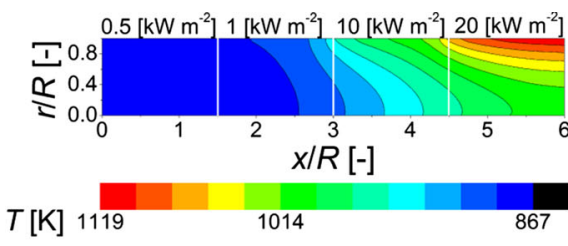

(a) $Q_{1}=0.5 \mathrm{~kW} \mathrm{~m}^{-2}, Q_{2}=1 \mathrm{~kW} \mathrm{~m}^{-2}$, $Q_{3}=10 \mathrm{~kW} \mathrm{~m}^{-2}, Q_{4}=20 \mathrm{~kW} \mathrm{~m}^{-2}$

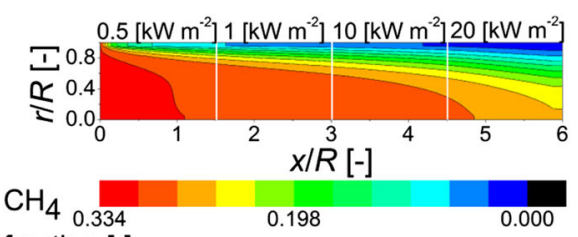
fraction [-]

(c) $Q_{1}=0.5 \mathrm{~kW} \mathrm{~m}{ }^{-2}, Q_{2}=1 \mathrm{~kW} \mathrm{~m}^{-2}$, $Q_{3}=10 \mathrm{~kW} \mathrm{~m}^{-2}, Q_{4}=20 \mathrm{~kW} \mathrm{~m}^{-2}$

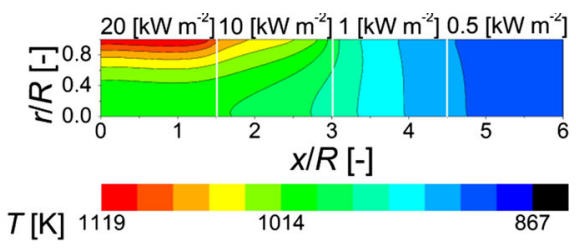

(b) $Q_{1}=20 \mathrm{~kW} \mathrm{~m}^{-2}, Q_{2}=10 \mathrm{~kW} \mathrm{~m}^{-2}$, $Q_{3}=1 \mathrm{~kW} \mathrm{~m}^{-2}, Q_{4}=0.5 \mathrm{~kW} \mathrm{~m}^{-2}$

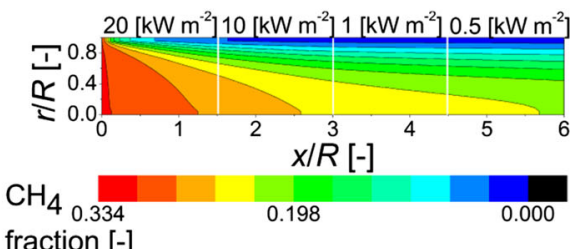

$$
\begin{aligned}
& \text { (d) } Q_{1}=20 \mathrm{~kW} \mathrm{~m}^{-2}, Q_{2}=10 \mathrm{~kW} \mathrm{~m}^{-2}, \\
& Q_{3}=1 \mathrm{~kW} \mathrm{~m}^{-2}, Q_{4}=0.5 \mathrm{~kW} \mathrm{~m}^{-2}
\end{aligned}
$$

Fig. 12 Distribution of temperature (a-b) and the mole fraction of methane (c-d) for different thermal boundary conditions; $\dot{w}_{\text {cat }}=2.5 \times 10^{5} \mathrm{~g} \mathrm{~m}^{-3}, u_{\text {in }}=0.25 \mathrm{~m} \mathrm{~s}^{-1}, S C=2$. 


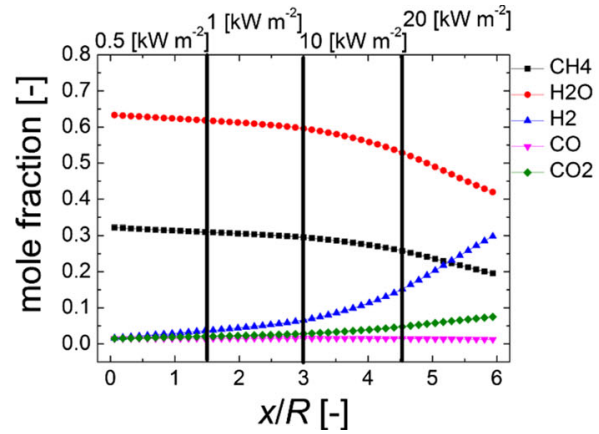

(a) $Q_{1}=0.5 \mathrm{~kW} \mathrm{~m}^{-2}, Q_{2}=1 \mathrm{~kW} \mathrm{~m}^{-2}$, $Q_{3}=10 \mathrm{~kW} \mathrm{~m}^{-2}, Q_{4}=20 \mathrm{~kW} \mathrm{~m}^{-2}$

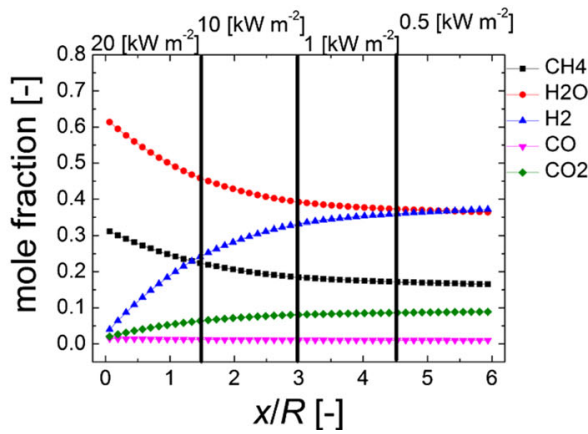

(b) $Q_{1}=20 \mathrm{~kW} \mathrm{~m}^{-2}, Q_{2}=10 \mathrm{~kW} \mathrm{~m}^{-2}$, $Q_{3}=1 \mathrm{~kW} \mathrm{~m}^{-2}, Q_{4}=0.5 \mathrm{~kW} \mathrm{~m}^{-2}$

Fig. 13 Average gas composition along the reformer; $\dot{w}_{\text {cat }}=2.5 \times 10^{5} \mathrm{~g} \mathrm{~m}^{-3}, u_{\text {in }}=0.25 \mathrm{~m} \mathrm{~s}^{-1}, S C=2$.

equal $\dot{w}_{\text {cat }}=2.5 \times 10^{5}\left[\mathrm{~g} \mathrm{~m}^{-3}\right]$ and inlet velocities were assumed to be equal $u_{\text {in }}=1.0[\mathrm{~m}$ $\left.\mathrm{s}^{-1}\right]$ and $u_{\text {in }}=0.1\left[\mathrm{~m} \mathrm{~s}^{-1}\right]$. The proper velocity should have allowed methane to be reacted completely inside the reformer while also supplying a sufficient amount of hydrogen into the cell stack. It can be described in a value of gas hourly space velocity (GHSV), which is a ratio of the fuel flow rate to the catalyst volume. As Figs. 10 and 11 indicate that for the applied boundary condition, an inlet flow rate $u_{\text {in }}=1.0\left[\mathrm{~m} \mathrm{~s}^{-1}\right]$ results in the decrease in time that the fuel spends in the reactor, thus methane cannot be completely converted and

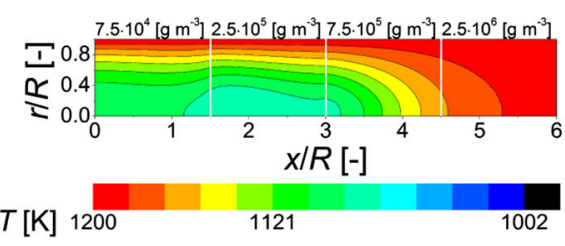

(a) $\dot{w}_{\text {cat }, 1}=7.5 \times 10^{4} \mathrm{~g} \mathrm{~m}^{-3}$ $\dot{w}_{\text {cat }, 2}=2.5 \times 10^{5} \mathrm{~g} \mathrm{~m}^{-3}$, $\dot{w}_{\text {cat }, 3}=7.5 \times 10^{5} \mathrm{~g} \mathrm{~m}^{-3}$, $\dot{w}_{\text {cat }, 4}=2.5 \times 10^{6} \mathrm{~g} \mathrm{~m}^{-3}$

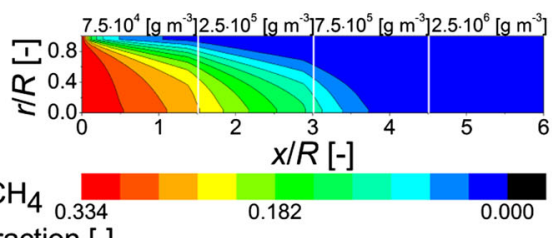

fraction [-]

$$
\begin{aligned}
& (\mathrm{c}) \dot{w}_{\text {cat }, 1}=7.5 \times 10^{4} \mathrm{~g} \mathrm{~m}^{-3} \\
& \dot{w}_{\text {cat }, 2}=2.5 \times 10^{5} \mathrm{~g} \mathrm{~m}^{-3} \\
& \dot{w}_{\text {cat }, 3}=7.5 \times 10^{5} \mathrm{~g} \mathrm{~m}^{-3} \\
& \dot{w}_{\text {cat }, 4}=2.5 \times 10^{6} \mathrm{~g} \mathrm{~m}^{-3}
\end{aligned}
$$

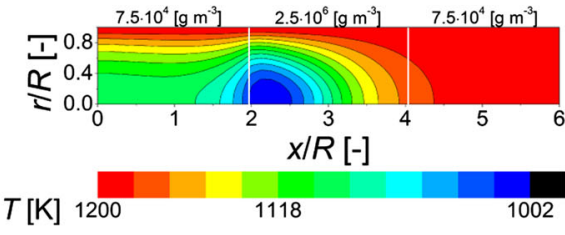

(b) $\dot{w}_{\text {cat }, 1}=7.5 \times 10^{4} \mathrm{~g} \mathrm{~m}^{-3}$, $\dot{w}_{\text {cat }, 2}=2.5 \times 10^{6} \mathrm{~g} \mathrm{~m}^{-3}$, $\dot{w}_{\text {cat }, 3}=7.5 \times 10^{4} \mathrm{~g} \mathrm{~m}^{-3}$ '

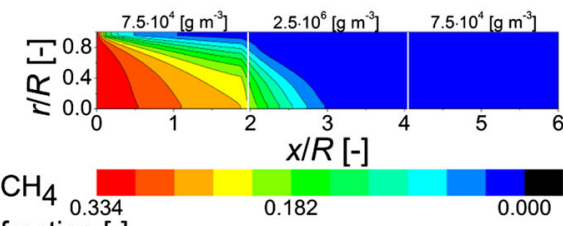

fraction [-]

$$
\begin{aligned}
& (\mathrm{d}) \dot{w}_{\text {cat }, 1}=7.5 \times 10^{4} \mathrm{~g} \mathrm{~m}^{-3} \\
& \dot{w}_{\text {cat }, 2}=2.5 \times 10^{6} \mathrm{~g} \mathrm{~m}^{-3} \\
& \dot{w}_{\text {cat }, 3}=7.5 \times 10^{4} \mathrm{~g} \mathrm{~m}^{-3}
\end{aligned}
$$

Fig. 14 Distribution of temperature (a-b) and the mole fraction of methane (c-d) for different catalyst distribution; $T=1200 \mathrm{~K}, u_{\mathrm{in}}=0.15 \mathrm{~m} \mathrm{~s}^{-1}, S C=2$. 


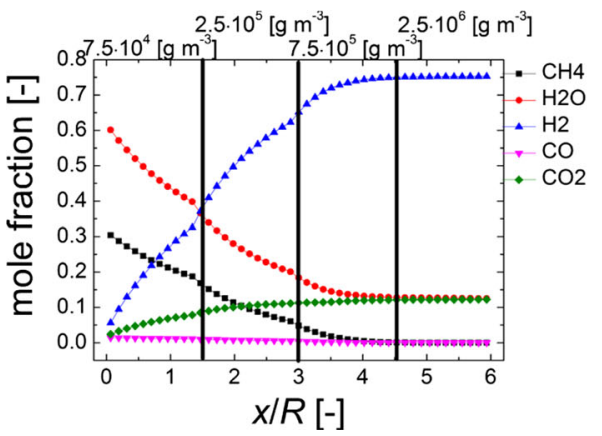

(a) $\dot{w}_{\text {cat }, 1}=7.5 \times 10^{4} \mathrm{~g} \mathrm{~m}^{-3}$ $\dot{w}_{\text {cat }, 2}=2.5 \times 10^{5} \mathrm{~g} \mathrm{~m}^{-3}$,

$\dot{w}_{\text {cat }, 3}=7.5 \times 10^{5} \mathrm{~g} \mathrm{~m}^{-3}$, $\dot{w}_{\text {cat }, 4}=2.5 \times 10^{6} \mathrm{~g} \mathrm{~m}^{-3}$

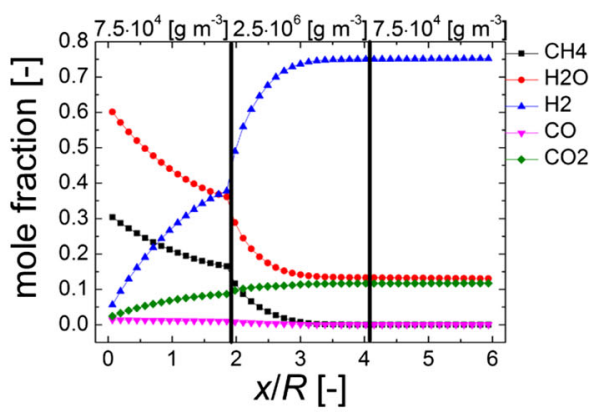

(b) $\dot{w}_{\text {cat }, 1}=7.5 \times 10^{4} \mathrm{~g} \mathrm{~m}^{-3}$, $\dot{w}_{\text {cat }, 2}=2.5 \times 10^{6} \mathrm{~g} \mathrm{~m}^{-3}$, $\dot{w}_{\text {cat }, 3}=7.5 \times 10^{4} \mathrm{~g} \mathrm{~m}^{-3}$

Fig. 15 Average gas composition along the reformer; $T=1200 \mathrm{~K}, u_{\text {in }}=0.15 \mathrm{~m} \mathrm{~s}^{-1}, S C=2$.

most of the methane leaves the reactor. Therefore, the GHSV should be controlled at the appropriate elevated level by lowering the fuel inlet velocity and increasing the length of the reformer.

\subsection{The effect of adopting locally controled heating zones}

Figures 12 and 13 present the results for different heat fluxes on the reformer wall. In each case the wall was divided into four heating zones. Figures 12a, c and 13a present results where heat flux increases gradually $Q_{1}=0.5\left[\mathrm{~kW} \mathrm{~m}^{-2}\right], Q_{2}=1\left[\mathrm{~kW} \mathrm{~m}{ }^{-2}\right], Q_{3}=10$ $\left[\mathrm{kW} \mathrm{m}^{-2}\right], Q_{4}=20\left[\mathrm{~kW} \mathrm{~m}^{-2}\right.$ ] for each heating zone, respectively. Figures $12 \mathrm{~b}, \mathrm{~d}$ and $13 \mathrm{~b}$ present the result where heat flux decreases gradually $Q_{1}=20\left[\mathrm{~kW} \mathrm{~m}^{-2}\right], Q_{2}=10[\mathrm{~kW}$ $\left.\mathrm{m}^{-2}\right], Q_{3}=1\left[\mathrm{~kW} \mathrm{~m}{ }^{-2}\right], Q_{4}=0.5\left[\mathrm{~kW} \mathrm{~m}^{-2}\right]$ for each heating zone, respectively. As can be seen in Figs. 12 and 13, the conversion rate of methane is higher in the case where heat flux decreased gradually. Also, the difference between the highest and lowest temperature was reduced slightly (from $250[\mathrm{~K}]$ to $224[\mathrm{~K}]$ ) when heat flux decreases gradually. The results indicate that even when the same amount of heat is supplied to the reactor, the findings might be significantly different depending on the location of the heating zone along the reactor. The results indicate that it is more efficient to increase the heat of the inlet of the reactor. Such an approach leads to a higher conversion rate of methane and a lower temperature gradient inside the reactor.

\subsection{The effect of localized catalyst density distribution}

The adaptation of localized catalyst density distribution zones could also increase fuel conversion and decrease the temperature gradient along the methane/steam reformer. The results of numerical computations are presented in Figs. 14 and 15. Figures 14a, c and 15a present results for four equally distributed catalyst zones with different catalyst weight densities: $\dot{w}_{\text {cat }, 1}=7.5 \times 10^{4}\left[\mathrm{~g} \mathrm{~m}^{-3}\right], \dot{w}_{\text {cat }, 2}=2.5 \times 10^{5}\left[\mathrm{~g} \mathrm{~m}^{-3}\right], \dot{w}_{\text {cat }, 3}=7.5 \times 10^{5}[\mathrm{~g}$ $\left.\mathrm{m}^{-3}\right], \dot{w}_{\text {cat }, 4}=2.5 \times 10^{6}\left[\mathrm{~g} \mathrm{~m}^{-3}\right]$, whereas Figs. $14 \mathrm{~b}, \mathrm{~d}$ and $15 \mathrm{~b}$ show the result of computations for three equally distributed catalyst weight density zones $\dot{w}_{\text {cat, } 1}=7.5 \times 10^{4}$ [g $\left.\mathrm{m}^{-3}\right], \dot{w}_{\text {cat }, 2}=2.5 \times 10^{6}\left[\mathrm{~g} \mathrm{~m}^{-3}\right], \dot{w}_{\text {cat }, 3}=7.5 \times 10^{4}\left[\mathrm{~g} \mathrm{~m}^{-3}\right]$. It can be seen from Fig. 15 
that the introduction of the catalyst zones along the reformer is an important solution that can allow for the control of reaction rate and temperature profile. In regions with denser catalysts, reforming reaction occurs faster, thus the conversion rate increases. However, areas with higher catalyst density could result in a higher temperature gradient at the catalyst zone inlet, what is shown in Fig. 14; the maximum temperature difference between the wall and the interior of the reactor increases from $130[\mathrm{~K}]$ to $198[\mathrm{~K}]$. Although, the proper choice of catalyst weight density zones can allow to control location of low temperature region inside the reformer. The results indicate that the catalyst distribution can improve the methane conversion rate wherein the temperature difference along the reformer can be controlled.

\section{General Conclusions}

This paper has presented numerical studies on the methane/steam reforming process on the $\mathrm{Ni} / Y S Z$ catalyst. The gas mixture composition was measured experimentally at the outlet of the reformer to establish the methane reforming rate and the kinetics of the reforming reaction. The reforming rate equation derived from the experimental data was used in the mathematical model to predict the gas composition at the outlet of the reformer and to verify the methane/steam reforming reaction model. Parametric studies have been conducted using the results of a two dimensional simulation. The temperature and species distribution of the longitudinal direction of the cylindrical plug-flow reformer has been presented. Finally, local heating and localized catalyst distributions were implemented in numerical computations to discuss the possibility of reducing the temperature gradients along the reformer. The conducted parametric studies leaded to the following conclusions:

1. The outlet composition of a methane/steam reformer reactor can be optimized to hydrogen rich fuel by adopting temperatures which are favorable for forward water-gas shift reaction.

2. Increasing catalyst density in the reactor leads to strong temperature gradients, therefore it is no at successful optimization strategy.

3. Temperature gradients can be suppressed if catalyst density is non-uniformly distributed (a higher catalyst density zone at the outlet of the reactor).

4. Adopting a localized catalyst distribution leads to a lower temperature gradient with a comparable conversion rate of methane.

5. It was shown that adopting a higher number of catalyst zones leads to a smaller temperature gradient.

6. The conducted numerical studies indicated that it is more efficient to increase the heat of the inlet of the reactor.

7. The proposed heating configuration allows for a smaller temperature gradient without a loss in the rate of consumed/produced methane/hydrogen.

\section{Nomenclature}

$A_{\text {st }} \quad$ Arrhenius constant $\left[\mathrm{mol} \mathrm{s}^{-1} \mathrm{~g}^{-1} \mathrm{~Pa}^{-(a+b)}\right]$

$a \quad$ order of reaction with respect to methane [-]

$a_{i} \quad$ coefficient in the discretized equation (unit depends on case)

$b \quad$ order of reaction with respect to water [-]

$C_{\mathrm{p}} \quad$ specific heat at constant pressure $\left[\mathrm{J} \mathrm{kg}^{-1} \mathrm{~K}^{-1}\right]$

$D_{j, \text { eff }}$ effective mass diffusivity of species $j\left[\mathrm{~m}^{2} \mathrm{~s}^{-1}\right]$

$E_{\mathrm{a}} \quad$ activation energy [ $\left.\mathrm{J} \mathrm{mol}^{-1}\right]$ 
$f \quad$ inertia coefficient [-]

$\Delta G_{\mathrm{sh}}$ change of standard Gibbs free energy of water-gas-shift reaction [ $\mathrm{J} \mathrm{mol}^{-1}$ ]

$\Delta H_{\mathrm{sh}} \quad$ enthalpy change accompanied with water-gas-shift reaction [ $\mathrm{J} \mathrm{mol}^{-1}$ ]

$\Delta H_{\mathrm{st}} \quad$ enthalpy change accompanied with methane/steam reforming reaction [ $\mathrm{J} \mathrm{mol}^{-1}$ ]

$K_{\mathrm{p}} \quad$ permeability $\left[\mathrm{m}^{2}\right]$

$K_{\text {sh }} \quad$ equilibrium constant of water-gas-shift reaction [-]

$k_{\mathrm{sh}}^{+/-} \quad$ rate constant of forward/backward water-gas-shift reaction $\left[\mathrm{mol} \mathrm{s}{ }^{-1} \mathrm{~m}^{-3} \mathrm{~atm}^{-2}\right.$ ]

$M_{i} \quad$ molar mass of species $i\left[\mathrm{~g} \mathrm{~mol}^{-1}\right]$

$n \quad$ number of species in system [-]

$n_{i} \quad$ volumetric flow rate of species $i\left[\mathrm{ml} \mathrm{min}^{-1}\right]$

$N C \quad$ nitrogen-to-methane ratio [-]

$P \quad$ pressure $[\mathrm{Pa}]$

$p_{j} \quad$ partial pressure of species $j[\mathrm{~Pa}]$

$Q \quad$ heat flux $\left[\mathrm{W} \mathrm{m}^{-3}\right]$

$Q_{\text {s }} \quad$ heat source/sink [ $\left[\mathrm{W} \mathrm{m}^{-3}\right]$

$Q_{\text {wall }} \quad$ wall heat flux $\left[\mathrm{W} \mathrm{m}^{-3}\right]$

$R \quad$ reactor radius [m]

$\bar{R} \quad$ universal gas constant, $\bar{R}=8.314472\left[\mathrm{~J} \mathrm{~mol}^{-1} \mathrm{~K}^{-1}\right]$

$R_{\mathrm{sh}} \quad$ rate of water-gas-shift reaction [mol s${ }^{-1} \mathrm{~m}^{-3}$ ]

$R_{\mathrm{st}} \quad$ rate of methane/steam reforming reaction $\left[\mathrm{mol} \mathrm{s}{ }^{-1} \mathrm{~m}^{-3}\right.$ ]

$r_{i} \quad$ grid $r$ dimension [m]

$r_{\mathrm{m}} \quad$ arithmetic mean between $r_{\mathrm{n}}$ and $r_{\mathrm{s}}[\mathrm{m}]$

$\Delta r \quad$ grid $r$ dimension $[\mathrm{m}]$

$\bar{S} \quad$ source therm (unit depends on case)

$S C \quad$ steam-to-methane ratio [-]

$S_{j} \quad$ mass source/sink of species $j\left[\mathrm{~kg} \mathrm{~s}^{-1} \mathrm{~m}^{-3}\right]$

$T \quad$ local average temperature both over the gas and solid phase [K] (Eq. 4)

$T$ temperature of the fuel conversion [K] (Eqs. 9, 10, 25)

$T_{\text {wall }} \quad$ wall temperature [K]

$U_{r} \quad$ gas phase average local velocity in $r$ direction $\left[\mathrm{m} \mathrm{s}^{-1}\right]$

$U_{x} \quad$ gas phase average local velocity in $x$ direction $\left[\mathrm{m} \mathrm{s}^{-1}\right]$

u velocity vector $\left[\mathrm{m} \mathrm{s}^{-1}\right]$

$V \quad$ volume of reactor $\left[\mathrm{m}^{3}\right]$

$w_{\text {cat }} \quad$ catalyst weight $[\mathrm{g}]$

$\dot{w}_{\text {cat }} \quad$ catalyst weight density $\left[\mathrm{g} \mathrm{m}^{-3}\right.$ ]

$x_{i} \quad$ grid $x$ dimension [m]

$x c r \quad$ methane conversion rate [-]

$\Delta x \quad$ grid $x$ dimension $[\mathrm{m}]$

$Y_{j} \quad$ mass fraction of chemical species $j[-]$

ycr carbon oxide conversion rate [-]

greek

$\epsilon_{0} \quad$ porosity [-]

$\Gamma \quad$ diffusive term (unit depends on case)

$\lambda_{\text {eff }} \quad$ effective thermal conductivity $\left[\mathrm{W} \mathrm{m}^{-1} \mathrm{~K}^{-1}\right.$ ]

$\lambda_{\mathrm{f}} \quad$ gas mixture thermal conductivity $\left[\mathrm{W} \mathrm{m}^{-1} \mathrm{~K}^{-1}\right.$ ]

$\lambda_{\mathrm{S}} \quad$ solid phase thermal conductivity $\left[\mathrm{W} \mathrm{m}^{-1} \mathrm{~K}^{-1}\right.$ ]

$\mu \quad$ viscosity [Pa s] 
$\rho_{0} \quad$ mixture density $\left[\mathrm{kg} \mathrm{m}^{-3}\right]$

$\phi \quad$ dependent variable (unit depends on case)

$\Psi_{r} \quad$ convective term in $r$ direction (unit depends on case)

$\Psi_{x} \quad$ convective term in $x$ direction (unit depends on case)

Acknowledgments This work was partially supported by the National Centre for Research and Development (Project HTRPL, Contract No. SP/J/1/166183/12). Additionally, the present work was partially supported by the PAN-JSPS Joint Research Project "Development of IGFC System with Oxygen and Hydrogen Storage Units".

Open Access This article is distributed under the terms of the Creative Commons Attribution 4.0 International License (http://creativecommons.org/licenses/by/4.0/), which permits unrestricted use, distribution, and reproduction in any medium, provided you give appropriate credit to the original author(s) and the source, provide a link to the Creative Commons license, and indicate if changes were made.

\section{References}

1. Yamamoto, O.: Solid oxide fuel cells: fundamental aspects and prospects. Electrochim. Acta. 45, 24232435 (2000)

2. Aguiar, P., Chadwick, D., Kershenbaum, L.: Modelling of an indirect internal reforming solid oxide fuel cell. Chem. Eng. Sci. 57, 1665-1677 (2002)

3. Ogden, J.M., Steinbugler, M.M., Kreutz, T.G.: A comparison of hydrogen, methanol and gasoline as fuels for fuel cell vehicles: implications for vehicle design and infrastructure development. J. Power Sources. 79, 143-168 (1999)

4. Brown, L.: A comparative study of fuels for on-board hydrogen production for fuel-cell-powered automobiles. Int. J. Hydrogen Energ. 26, 381-397 (2001)

5. Xu, J., Froment, G.F.: Methane steam reforming, methanation and water-gas shift: I. Intrinsic kinetics. AIChE J. 35, 88-96 (1989)

6. Xu, J., Froment, G.F.: Methane steam reforming: II. Diffusional limitations and reactor simulation. AIChE J. 35, 97-103 (1989)

7. Brus, G., Szmyd, J.: Numerical Modelling of Radiative Heat Transfer in an SOFC System. ECS Trans. 7, 2013-2020 (2007)

8. Brus, G., Szmyd, J.S.: Numerical modelling of radiative heat transfer in a internal indirect reforming-type SOFC. J. Power Sources. 181, 8-16 (2008)

9. Brus, G., Kolenda, Z., Kimijima, S., Szmyd, J.S.: An analysis of heat transfer process in an internal indirect reforming type SOFC. In: Proceedings of the 14th International Heat Transfer Conference, vol. 5, Washington, DC. ASME, 71-80 (2010)

10. Brus, G., Kimijima, S., Szmyd, J.S.: Experimental and numerical analysis of transport phenomena in an internal indirect fuel reforming type Solid Oxide Fuel Cells using Ni/SDC as a catalyst. J. Phys.: Conf. Ser. 395, 012159 (2012)

11. Settar, A., Nebbali, R., Madani, B., Abboudi, S.: Numerical investigation on the wall-coated steam methane reformer improvement: Effects of catalyst layer patterns and metal foam insertion. Int. J. Hydrogen Energ. 40, 8966-8979 (2015)

12. Komatsu, Y., Kimijima, S., Szmyd, J.S.: Performance analysis for the part-load operation of a solid oxide fuel cellmicro gas turbine hybrid system. Energy. 35, 982-988 (2010)

13. Komatsu, Y., Kimijima, S., Szmyd, J.S.: Numerical analysis on dynamic behavior of solid oxide fuel cell with power output control scheme. J. Power Sources. 223, 232-245 (2013)

14. Kuwahara, F., Yamane, T., Nakayama, A.: Large eddy simulation of turbulent flow in porous media. Int. Commun. Heat Mass. 33, 411-418 (2006)

15. Nield, D.A., Bejan, A.: Convection in porous media. Springer, New York (2006)

16. Carbonell, R.G., Whitaker, S.: Heat and Mass Transfer in Porous Media. In: Bear, J., Corapcioglu, M.Y. (eds.) Fundamentals of Transport Phenomena in Porous Media, pp. 121-198. Martinus Nijhoff Publishers, Dordrecht (1984)

17. Vafai, K., Tien, C.L.: Boundary and inertia effects on flow and heat transfer in porous media. Int. J. Heat Mass Tran. 24, 195-203 (1981) 
18. Hassan, Y., Dominguez-Ontiveros, E.: Flow visualization in a pebble bed reactor experiment using PIV and refractive index matching techniques. Nucl. Eng. Des. 238, 3080-3085 (2008)

19. Suzuki, K., Iwai, H., Nishino, T.: Electrochemical and Thermo-Fluid Modeling of a Tubular Solid Oxide Fuel Cell with Accompanying Indirect Internal Fuel Reforming. In: Sunden, B., Faghri, M. (eds.) Transport Phenomena in Fuel Cells, pp. 83-131. WIT Press, Southampton (2005)

20. Nishino, T., Szmyd, J.S.: Numerical Analysis of a Cell-Based Indirect Internal Reforming Tubular SOFC Operating With Biogas. J. Fuel Cell Sci. Technol. 7, 051004 (2010)

21. Poling, B.E., Prausnitz, J.M., John Paul, O., Reid, R.C.: The properties of gases and liquids. McGrawHill, New York (2001)

22. Nagata, S., Momma, A., Kato, T., Kasuga, Y.: Numerical analysis of output characteristics of tubular SOFC with internal reformer. J. Power Sources. 101, 60-71 (2001)

23. Achenbach, E., Riensche, E.: Methane/steam reforming kinetics for solid oxide fuel cells. J. Power Sources. 52, 283-288 (1994)

24. Patankar, S.: Numerical heat transfer and fluid flow. Hemisphere, Washington (1980)

25. Ferziger, J.H., Peric, M.: Computational methods for fluid dynamics. Springer, Berlin (1996)

26. Wei, J., Iglesia, E.: Isotopic and kinetic assessment of the mechanism of reactions of $\mathrm{CH}_{4}$ with $\mathrm{CO}_{2}$ or $\mathrm{H}_{2} \mathrm{O}$ to form synthesis gas and carbon on nickel catalysts. J. Catal. 224, 370-383 (2004)

27. Brus, G., Komatsu, Y., Kimijima, S., Szmyd, J.S.: An Analysis of Biogas Reforming Process on Ni/YSZ and Ni/SDC Catalysts. Int. J. Thermodyn. 15, 43-51 (2012)

28. Yakabe, H., Ogiwara, T., Hishinuma, M., Yasuda, I.: 3-D model calculation for planar SOFC. J. Power Sources. 102, 144-154 (2001)

29. Ahmed, K., Foger, K.: Kinetics of internal steam reforming of methane on Ni/YSZ-based anodes for solid oxide fuel cells. Catal. Today. 63, 479-487 (2000)

30. Hosseini, S., Ahmed, K., Tad, M.O.: CFD model of a methane fuelled single cell SOFC stack for analysing the combined effects of macro/micro structural parameters. J. Power Sources. 234, 180-196 (2013)

31. Achenbach, E.: Three-dimensional and time-dependent simulation of a planar solid oxide fuel cell stack. J. Power Sources. 49, 333-348 (1994)

32. Brus, G.: Experimental and numerical studies on chemically reacting gas flow in the porous structure of a solid oxide fuel cells internal fuel reformer. Int. J. Hydrogen Energ. 37, 17225-17234 (2012)

33. Sciazko, A., Komatsu, Y., Brus, G., Kimijima, S., Szmyd, J.S.: An Application of Generalized Least Squares Method to an Analysis of Methane/Steam Reforming Process on a Ni/YSZ Catalyst. ECS Trans. 57, 2987-2996 (2013)

34. Sciazko, A., Komatsu, Y., Brus, G., Kimijima, S., Szmyd, J.S.: A novel approach to the experimental study on methane/steam reforming kinetics using the Orthogonal Least Squares method. J. Power Sources. 262, 245-254 (2014)

35. Sciazko, A., Komatsu, Y., Brus, G., Kimijima, S., Szmyd, J.S.: A novel approach to improve the mathematical modelling of the internal reforming process for solid oxide fuel cells using the orthogonal least squares method. Int. J. Hydrogen Energ. 39, 16372-16389 (2014)

36. Tsolakis, A., Megaritis, A.: Catalytic exhaust gas fuel reforming for diesel engines-effects of water addition on hydrogen production and fuel conversion efficiency. Int. J. Hydrogen Energ. 29, 1409-1419 (2004) 